\title{
PENGARUH METODE FERMENTASI SUBSTRAT PADAT DAN SUBSTRAT TERENDAM PADA BIJI SORGUM TERHADAP KUALITAS TEPUNG
}

\author{
[Sorghum Flour Characteristics as Affected by Solid State and Submerged \\ Fermentation Methods]
}

\author{
Erni Sofia Murtini ${ }^{\star}$, M. Iqbal Prawira-Atmaja, dan Aji Sutrisno \\ Jurusan Teknologi Hasil Pertanian, Fakultas Teknologi Pertanian, Universitas Brawijaya, Malang
}

Diterima 03 April 2016 / Disetujui 23 Juni 2016

\begin{abstract}
The utilization of sorghum as food products is restricted by its lack of digestibility and the presence of anti-nutrients factors. Fermentation process has been recommended to improve cereal-based flour quality. This study was aimed to evaluate the effect of two fermentation methods namely solid state (a method adopting tempeh processing procedure with fermentation course of 60 and 72 h) and submerged fermentation (similar to ampok processing procedure with fermentation course of 72 and $84 \mathrm{~h}$ ). The fermented-sorghum grains were then dried, and milled to produce sorghum flour. Analyses of proximate, physical poperties (particle size index/PSI, Water Absorption Index/WAI, swelling power) and amylograph profiles were carried out to obtain the flour characteristics. The results showed that both fermentation methods significantly influenced the proximate, physical and amilograph properties of the sorghum flour. Solid state fermentation of sorghum grains decreased the starch content, reduced its lightness, swelling power and viscosity, while increased the PSI and WAI. However, the solid state fermentation did not significantly change the protein, fat, ash and moisture content of the sorghum flour. Submerged fermentation of sorghum grain decreased the starch and protein content, increased the lightness, swelling power and viscosity, while did not significantly modify fat, ash and moisture content of the flour. Based on the characteristics obtained, it is suggested that sorghum flour made from solid state fermented-sorghum grain may be applicable for making-not viscous-food products, such as porridge. On the other side, the sorghum flour made from sub merged-fermented-sorghum grain may be used as thickening agent, binder or for making highly viscous food products.
\end{abstract}

Keywords: fermentation, solid state (tempeh), sorghum flour characteristics, submerged fermentation (ampok)

\begin{abstract}
ABSTRAK
Pemanfaatan sorgum sebagai bahan pangan dibatasi oleh rendahnya daya cerna dan juga keberadaan anti nutrisi. Fermentasi sereal telah dilaporkan dapat meningkatkan kualitas tepung sorgum. Penelitian ini bertujuan mengetahui karakteristik tepung sorgum yang dihasilkan dari biji yang difermentasi menggunakan dua metode yaitu substrat padat (mengikuti prosedur pembuatan tempe dengan lama fermentasi 60 dan 72 jam) dan substrat terendam (mengikuti prosedur pembuatan ampok dengan lama fermentasi 72 dan 84 jam). Biji sorgum terfermentasi kemudian dikeringkan dan digiling untuk meng hasilkan tepung sorgum. Analisis proksimat, sifat fisik (indeks ukuran partikel, indeks penyerapan air, swelling, dan viskositas menggunakan Brabender Amilograph) dilakukan untuk karakterisasi tepung sorgum yang dihasilkan. Hasil penelitian menunjukkan bahwa kedua metode fermentasi mempengaruhi proksimat, sifat fisik dan amilografi tepung sorgum yang dihasilkan. Fermentasi biji sorgum metode substrat padat menurunkan kandungan pati, kecerahan warna tepung, swelling power dan viskositas, meningkatkan PSI dan WAI, namun tidak mengubah kandungan protein, lemak, abu dan air. Fermentasi biji sorgum metode submerged menurunkan kadar pati dan protein, meningkatkan kecerahan, swelling power dan viskositas, namun tidak mem pengaruhi kadar lemak dan abu tepung sorgum. Berdasarkan sifat tersebut, tepung sorgum hasil fermentasi substrat padat mungkin sesuai diaplikasikan untuk produk dengan sifat 'cair', sedangkan tepung sorgum hasil fermentasi substrat terendam mungkin sesuai untuk bahan pengental atau bahan pengisi dan produk dengan viskositas tinggi.
\end{abstract}

Kata kunci: fermentasi, karakteristik tepung sorgum, substrat padat (tempe), substrat terendam (ampok)

*Penulis Korespondensi:

E-mail: erni.murtini@ub.ac.id 


\section{PENDAHULUAN}

Sorgum merupakan serealia penting sebagai bahan pangan setelah gandum, padi, jagung dan barley. Sorgum sebagian besar di konsumsi oleh negara berkembang di Afrika, Asia, Amerika tengah, Karibian, Amerika selatan (Taylor dan Anyango, 2011). Keistimewaan dari tanaman ini adalah mampu tumbuh dan berkembang pada daerah marginal dan kering di mana tanaman serelia lainnya tidak dapat tumbuh. Sorgum, sebagai sumber pangan, memiliki kandungan karbohidrat berkisar $65-80 \%$ dan protein 7-15\% Althwab et al., 2015) cukup tinggi bila dibandingkan jagung dengan kandungan karbohidrat $72,4 \%$ dan protein $8,7 \%$ atau singkong dengan karbohidrat $34,7 \%$ dan protein $1,2 \%$ (Soeranto, 2006). Analisis secara genome, biokimia dan imonokimia membuktikan bahwa sorgum tidak mengandung senyawa toxic gliadin-like peptide sehingga memiliki keuntungan sebagai sereal yang menyehatkan yang bebas gluten serta aman dikonsumsi oleh penderita celiac disease (Pontieri et al., 2013). Sorgum juga berpotensi sebagai pangan fungsional yang memberikan efek kesehatan karena senyawa fitokimia yang dimiliki (Taylor dan Duodu, 2014).

Berdasarkan kenampakan dan total fenol, sorgum dapat dibagi menjadi sorgum putih (foodtype sorghum) yang memiliki total fenol yang rendah, sorgum merah yang memiliki fenol cukup tinggi dan sorgum coklat yang memiliki testa berwarna coklat dan memiliki kadar tannin tinggi (Awika dan Rooney, 2004). Sorgum lokal varietas coklat adalah salah satu jenis sorgum yang banyak tumbuh di Indonesia. Namun, pemanfaatannya masih terbatas sebagai pakan ternak dan jarang digunakan sebagai sumber pangan. Keterbatasan pemanfaatan sorgum cokelat sebagai sumber pangan dikarenakan keberadaan senyawa anti gizi seperti tanin dan asam fitat (Awika dan Rooney, 2004; Kaufman et al., 2013). Tanin dan fitat dapat menurunkan daya cerna protein. Tanin mampu mengikat dan mengendapkan protein sejumlah 12 kali dari beratnya, sedangkan molekul fitat tersusun atas 6 grup fosfat yang memiliki kemampuan mengkelat dan membentuk komplek tidak larut dengan protein (Duodu et al., 2003).

Metode fermentasi dapat dikelompokkan menjadi solid state (substrat padat) dan submerged (substrat terendam). Contoh pangan khas Indonesia yang diproduksi dengan metode substrat padat adalah tempe, sedangkan contoh produk yang diproses dengan fermentasi metode substrat terendam adalah ampok. Tempe diproduksi dari kedelai yang difermentasi dengan menggunakan strains mikroba Rizopus sp. seperti: $R$. oligosporus, $R$. stolonifer, $R$. oryzae, dan $R$. arrhizus (Cuevasrodriguez et al., 2004; Feng, 2006). Sedangkan ampok adalah produk pangan berbasis jagung yang telah dihancurkan kasar dan kemudian dilakukan proses perendaman pada air selama 2-3 hari (Aini et al., 2010; Farasara et al., 2014). Proses perendaman jagung merupakan proses fermentasi, dimana terdapat mikroba yang tumbuh seperti: kapang Penicillium citrinum, P. chrysogenum, A. flavus, $A$. niger, Rhizopus stolonifer, $R$. oryzae, Fusarium oxysporum, Acremonium strictum, khamir Candida famata, Kodamaea ohmeri, Candida krusei/incospicua, serta bakteri asam laktat L. plantarum 1a, Pediococcus pentosaceus, L. brevis 1, L. plantarum 1b, dan L. paracasei ssp paracasei 3 (Rahmawati et al., 2013).

Proses fermentasi berperan terhadap terjadinya degradasi sebagian senyawa kompleks menjadi senyawa yang lebih sederhana sehingga menjadi lebih larut. Selain itu fermentasi juga mendegradasi senyawa kimia seperti tanin, polifenol, asam fitat oleh enzim-enzim mikroba (Hassan et al., 2006). Penelitian oleh Elkhalifa et al. (2005) melaporkan bahwa sorgum yang difermentasi secara tradisional di Sudan diperoleh peningkatan yang signifikan terhadap sifat fungsional dan kandungan gizi dari tepung sorgum.

Kombinasi perkecambahan dan fermentasi pada biji sorgum pada waktu yang berbeda dihasilkan penurunan kadar tanin dan asam fitat yang berpengaruh terhadap peningkatan bioavibilitas zat besi saat dikonsumsi (Kayode et al., 2013). Penelitian Murtini et al. (2011) melaporkan bahwa sorgum yang difermentasi metode tempe selama 60 jam dan 72 jam memiliki penurunan antigizi yang signifikan dan peningkatan daya cerna protein secara in vitro. Sedangkan sorgum dengan proses fermentasi ampok selama 72 jam dan 84 jam adalah perlakuan terbaik (Sujatmiko, 2009).

Peningkatan kualitas nutrisi tepung sorgum dapat dilakukan dengan mengadopsi metode fermentasi tradisional khas dari Indonesia yaitu ampok dan tempe. Namun demikian, untuk dapat diaplikasikan perlu diketahui karakteristik fisik dan kimia dari tepung sorgum yang berasal dari sorgum dengan perlakuan fermentasi metode substrat padat adopsi tempe dan metode substrat terendam adopsi ampok. Informasi ini penting untuk menentukan penggunaan tepung sorgum dalam formulasi produk pangan.

\section{BAHAN DAN METODE}

\section{Bahan}

Bahan utama yang digunakan adalah sorgum lokal varietas coklat yang diperoleh dari Desa Rejoso, Kecamatan Grati, Kabupaten Pasuruan, Jawa Timur. Sorgum yang di dapat kemudian disosoh dengan penyosoh beras dan diulang hingga 
empat kali penyosohan. Biji sorgum yang telah disosoh kemudian di tepungkan dengan mesin penepung (Milcent Magnam Magnetic, India).

\section{Fermentasi biji sorgum metode substrat padat}

Fermentasi biji sorgum metode substrat padat mengacu pada metode pembuatan tempe sorgum (Andayani, 2008). Biji sorgum dicuci bersih dari kotoran dan benda asing, kemudian ditimbang tepat berat bahan dan direndam di dalam air dengan rasio 1:3 (bahan:air). Sorgum di rendam selama 24 jam, kemudian air rendaman dibuang dan sorgum ditiriskan. Selanjutnya sorgum direbus pada suhu $100 \pm 2^{\circ} \mathrm{C}$ selama 10 menit hingga biji sorgum sedikit lunak. Biji sorgum ditiriskan dan didinginkan agar diperoleh kondisi optimum untuk pertumbuhan jamur tempe. Ragi tempe (Raprima-LIPI Bandung) sebanyak $0,1 \%$ (b/b) di taburkan pada biji sorgum, Sorgum dikemas dalam plastik berpori dan diinkubasi suhu ruang $\left(30 \pm 3^{\circ} \mathrm{C}\right)$ selama 60 dan 72 jam.

\section{Fermentasi biji sorgum metode substrat teren- dam}

Fermentasi biji sorgum metode substrat terendam mengacu pada proses fermentasi ampok sorgum (Utami, 2008). Biji sorgum yang telah disosoh kemudian ditimbang sebanyak $100 \mathrm{~g}$ dan ditambahkan air dengan perbandingan 1:2. Perendaman ini merupakan fermentasi ampok sorgum coklat. Perlakuan proses perendaman sorgum dilakukan pada suhu $30 \pm 3^{\circ} \mathrm{C}$ selama 72 atau 84 jam.

\section{Pembuatan tepung sorgum}

Sorgum hasil dari proses fermentasi metode substrat padat dan substrat terendam dikeringkan dalam pengering kabinet dengan suhu $50 \pm 3^{\circ} \mathrm{C}$ selama 12 jam. Produk yang sudah kering kemudian digiling dengan menggunakan mesin penepung hingga halus. Tepung yang dihasilkan kemudian diayak dengan ukuran ayakan 80 mesh.

\section{Analisis}

Analisis kimia yang dilakukan dalam penelitian ini meliputi analisis proksimat berdasarkan metode AOAC (1990). Sedangkan analisis sifat fisik tepung sorgum meliputi: Water absorption index berdasarkan Anderson et al. (1969) dalam Cuevas-rodriguez et al. (2006); Particle size index (Bedolla dan Rooney, 1982 dalam Cuevas-Rodriguez et al., 2006); swelling power tepung sorgum (AACC, 1995 dengan modifikasi); Derajat Putih tepung sorgum menggunakan Colour Spectrophotometer model CR400/410 (merk Minolta, USA); dan analisis viskositas pasta tepung sorgum (sifat amilograf) menggunakan alat Brabender Amiloghraph (Brabender Amilograph, Germany).

\section{Analisis data}

Analisis data hasil uji dari karakteristik tepung sorgum yang diperoleh menggunakan program $I B M^{9}$ $S P S S^{\circledR}$ Statistic 23. Data yang diperoleh dianalisis menggunakan one way ANOVA dengan tingkat signifikansi 95\% dan dilanjutkan dengan uji Duncan Multiple Range Test (DMRT) jika terdapat perbedaan pengaruh yang nyata pada variabel bebas.

\section{HASIL DAN PEMBAHASAN}

\section{Proksimat tepung sorgum}

Hasil analisis proksimat biji sorgum terfermentasi diasajikan pada Tabel 1. Pati merupakan komponen nutrisi utama sorgum yang sebagian besar terletak di bagian endosperma (SernaSaldivar dan Rooney, 1995). Tepung sorgum tanpa perlakuan fermentasi (kontrol) memiliki kandungan pati sebesar 71,89\%. Kedua perlakuan fermentasi secara nyata berpengaruh terhadap penurunan kadar pati tepung sorgum. Sorgum dengan perlakuan fermentasi secara substrat padat memiliki kandungan pati 69,23 dan 65,66\% (fermentasi 60 dan 72 jam) sedangkan sorgum dengan perlakuan fermentasi substrat terendam kadar patinya adalah 68,77 dan $67,34 \%$ (fermentasi 72 dan 84 jam).

Tabel 1. Pengaruh fermentasi biji sorgum secara substrat padat dan substrat terendam terhadap proksimat tepung sorgum

\begin{tabular}{|c|c|c|c|c|c|}
\hline Perlakuan & Pati (\%) & Protein (\%) & Lemak (\%) & Abu (\%) & Air (\%) \\
\hline Sorgum tanpa fermentasi (Kontrol) & $71,89 \pm 0,1$ & $10,27 \pm 0,1$ & $0,64 \pm 0,1$ & $0,43 \pm 0,1$ & $9,53 \pm 0,2$ \\
\hline $\begin{array}{l}\text { Sorgum dengan fermentasi } \\
\text { substrat padat } 60 \text { Jam }\end{array}$ & $69,23 \pm 1,2^{a}$ & $9,86 \pm 0,4^{\mathrm{a}}$ & $0,53 \pm 0,1^{a}$ & $0,36 \pm 0,1^{a}$ & $9,81 \pm 0,2^{a}$ \\
\hline $\begin{array}{l}\text { Sorgum dengan fermentasi } \\
\text { substrat padat } 72 \text { Jam }\end{array}$ & $65,66 \pm 0,3^{c}$ & $10,33 \pm 0,3^{a}$ & $0,56 \pm 0,1^{a}$ & $0,47 \pm 0,1^{\mathrm{a}}$ & $9,04 \pm 0,6^{\mathrm{ab}}$ \\
\hline $\begin{array}{l}\text { Sorgum dengan fermentasi } \\
\text { substrat terendam } 72 \text { Jam }\end{array}$ & $68,77 \pm 0,5^{\mathrm{a}}$ & $7,86 \pm 0,8^{b}$ & $0,53 \pm 0,1^{a}$ & $0,45 \pm 0,1^{a}$ & $9,15 \pm 0,2^{\mathrm{ab}}$ \\
\hline $\begin{array}{l}\text { Sorgum dengan fermentasi } \\
\text { substrat terendam } 84 \text { Jam }\end{array}$ & $67,34 \pm 0,3^{b}$ & $7,76 \pm 0,7^{b}$ & $0,56 \pm 0,1^{a}$ & $0,27 \pm 0,2^{a}$ & $8,63 \pm 0,4^{b}$ \\
\hline
\end{tabular}

Keterangan: Data \pm standar deviasi dari tiga ulangan. Angka yang diikuti huruf yang sama pada kolom yang sama menunjukkan tidak berbeda nyata dengan uji Duncan dengan taraf $P=0,05$ 
Selama proses fermentasi, molekul pati sorgum terhidrolisis menjadi molekul yang lebih sederhana seperti gula dan sebagian menjadi alkohol (Schons et al., 2012; Elbaloula et al., 2014). Granula pati yang menjadi lebih kecil memiliki luas permukaan yang lebih luas, menyebabkan enzim akan lebih mudah menghidrolisis (Singh et al., 2010). Penurunan kadar pati pada sorgum juga dilaporkan oleh Elkhalifa et al., (2004), kandungan pati sorgum varietas Tabat yang difermentasi dengan metode tradisional Sudan menurun dari $74,45 \%$ menjadi $61,03 \%$.

Protein merupakan komponen terbesar kedua pada tepung sorgum. Kandungan protein tepung sorgum berkisar 12,3\% (FAO, 1995). Hasil penelitian menunjukkan bahwa tepung sorgum tanpa perlakuan fermentasi memiliki kadar protein sebesar $10,27 \%$. Perlakuan fermentasi secara substrat padat selama 72 jam cenderung meningkatkan, namun tidak mengubah secara signifikan kandungan protein sorgum (10,33\%) pada tepung sorgum yang dihasilkannya. Peningkatan kadar protein pada tepung sorgum hasil perlakuan fermentasi tempe dikarenakan adanya peningkatan biomassa dari mikroorganisme yang berperan dalam proses fermentasi (Cuevas-Rodriguez et al., 2004). Namun, fermentasi biji sorgum secara substrat terendam menurunkan cukup banyak protein (23-24\%), sehingga tepung sorgum yang dihasilkan hanya memiliki protein 7,86 dan $7,76 \%$ setelah mengalami fermentasi selama 72 dan 84 jam. Penurunan kadar protein dari tepung sorgum hasil fermentasi substrat terendam dapat diakibatkan oleh terjadinya hidrolisis protein baik oleh enzim yang dihasilkan oleh mikroba alami yang terdapat dalam air perendam maupun aktivasi enzim protease yang terdapat pada biji sorgum. Enzim proteolitik, menurut Kohajdova dan Karavicona (2007); Pranoto et al., (2013) lebih lanjut memetabolisme fraksi protein tak larut ke dalam bentuk peptida dan amonia serta senyawa aroma.

Kedua metode fermentasi cenderung menurunkan jumlah lemak pada sorgum pada kisaran 0,53\%, meskipun secara uji statistik kadar lemak tidak berbeda nyata pada uji DMRT pada taraf $P=0,05$. Penurunan kadar lemak selama fermentasi dikarenakan adanya aktivitas pemanfaatan lemak sebagai sumber energi. Ruiz-Teran dan Owen (1996) dalam Cuevas-Rodriguez et al. (2004) menyatakan bahwa terjadi pengurangan kadar lemak pada tahap awal fermentasi. Hal tersebut diperkirakan karena terjadi reaksi oksidasi serta pemanfaatan dari asam lemak oleh kapang sebagai sumber energi. Penurunan kadar lemak selama proses perendaman disebabkan oleh meningkatnya aktivitas enzim lipolitik yang akan menghidrolisis lemak menjadi asam lemak dan gliserol (Inyang dan Zakari, 2008).
Kandungan lemak dalam tepung berpengaruh terhadap sifat dan karakter tepung selama proses pengolahan. menurut Chanapamokkhot dan Thongngam (2007) lemak yang membentuk kompleks dengan amilosa dapat berkontribusi mempengaruhi sifat pasting dan pengembangan pati dan tepung. Rendahnya komponen lemak pada sorgum cokelat varietas lokal dapat menguntungkan produk tepung sorgum karena kerusakan akibat oksidasi lemak sangat minim sehingga akan memperpanjang umur simpan tepung.

\section{Derajat kecerahan dan karakteristik fisik tepung sorgum}

Warna merupakan parameter utama pada tepung. Sorgum yang digunakan sebgai bahan baku adalah sorgum coklat, sehingga tepung yang dihasilkan memiliki warna asli yang cenderung cokelat kemerahan. Tabel 2 menunjukkan bahwa tepung sorgum hasil fermentasi substrat padat memiliki warna yang lebih gelap (nilai $L^{*}$ lebih rendah) dibandingkan dengan kontrol maupun dengan tepung sorgum hasil fermentasi substrat terendam.

Tabel 2. Pengaruh fermentasi biji sorgum secara substrat padat dan substrat terendam terhadap karakteristik warna tepung sorgum

\begin{tabular}{|c|c|c|c|}
\hline Perlakuan & $\mathrm{L}$ & $\mathrm{a}^{*}$ & $\mathrm{~b}^{*}$ \\
\hline $\begin{array}{l}\text { Sorgum tanpa } \\
\text { fermentasi (Kontrol) }\end{array}$ & $62,6 \pm 0,2^{0}$ & $15,76 \pm 0,1^{a}$ & $15,83 \pm 0,1^{0}$ \\
\hline $\begin{array}{l}\text { Sorgum fermentasi } \\
\text { substrat padat } \\
60 \text { Jam }\end{array}$ & $61,5 \pm 0,3^{c}$ & $15,47 \pm 0,5^{\mathrm{D}}$ & $16,63 \pm 0,1^{a}$ \\
\hline $\begin{array}{l}\text { Sorgum fermentasi } \\
\text { substrat padat } \\
72 \text { Jam }\end{array}$ & $61,0 \pm 0,3^{c}$ & $15,07 \pm 0,5^{c}$ & $16,83 \pm 0,5^{a}$ \\
\hline $\begin{array}{l}\text { Sorgum fermentasi } \\
\text { substrat terendam } \\
72 \text { Jam }\end{array}$ & $63,1 \pm 0,3^{\mathrm{D}}$ & $14,43 \pm 0,2^{a}$ & $15,23 \pm 0,3^{c}$ \\
\hline $\begin{array}{l}\text { Sorgum fermentasi } \\
\text { substrat terendam } \\
84 \text { Jam }\end{array}$ & $64,5 \pm 0,3^{a}$ & $14,97 \pm 0,4^{\mathrm{c}}$ & $15,60 \pm 0,3^{b c}$ \\
\hline $\begin{array}{l}\text { terangan: Data } \\
\text { Angka yang diik } \\
\text { sama menunju } \\
\text { Duncan dengan }\end{array}$ & dak & si dari & ular \\
\hline
\end{tabular}

Penurunan nilai kecerahan warna pada tepung hasil fermentasi substrat padat dipengaruhi oleh warna miselia jamur tempe yang berperan dalam fermentasi. Jamur utama pada tempe adalah Rizopus oligosporus dan Aspergillus orizae, yang akan cenderung berwarna kehitaman dengan bertambahnya waktu fermentasi. Sementara itu, warna yang lebih cerah dihasilkan dari tepung yang difermentasi menggunakan metode substrat terendam. Senyawa pewarna utama pada sorgum adalah antosianin yang dapat diekstrak dengan efektif menggunakan larutan aseton 70\% (Awika dan Rooney, 2004), artinya komponen ini masih dapat 
terlarut dalam air selama proses perendaman dalam fermentasi metode substrat terendam. Hal ini menyebabkan keberadaan pigmen dalam biji yang terfermentasi akan berkurang, sehingga berakibat pada meningkatnya kecerahan tepung sorgum yang dihasilkan. Cuevas-Rodriguez et al. (2004) telah melaporkan terjadi peningkatkan nilai $L^{*}$ warna tepung jagung setelah perlakuan perendaman biji.

Indeks ukuran partikel menunjukkan bahwa tepung sorgum yang tanpa perlakuan fermentasi memiliki nilai Particle Size Index (PSI) sebesar $55,96 \%$. Perlakuan fermentasi biji sorgum baik metode solid state maupun submerged meningkatkan PSI tepung sorgum, antara 6,7-13,07\% dari PSI tepung sorgum tanpa fermentasi. PSI menunjukkan jumlah tepung yang lolos ayakan 200 mesh dibagi dengan berat awal tepung, sehingga semakin tinggi PSI menunjukkan semakin kecil ukuran partikel tepung (Cuevas-Rodriguez et al., 2006). Fermentasi biji sorgum baik metode substrat padat maupun substrat terendam keduanya menyebabkan kekerasan (tekstur) biji sorgum menurun, sehingga lebih mudah ditepungkan dan menghasilkan partikel tepung yang lebih halus. Hasil yang sama dilaporkan oleh Cuevas-Rodriguez et al. (2004) bahwa tepung jagung yang difermentasi dengan metode tempe menunjukkan peningkatan nilai PSI dari $71,94 \%$ menjadi $79,59 \%$.

Nilai Indeks penyerapan air (WAI) pada tepung sorgum yang didapat dari sorgum tanpa fermentasi secara statistik tidak berbeda nyata dengan tepung yang dihasilkan dari biji yang difermentasi secara substrat terendam. Namun demikian, tepung yang diproses dari biji sorgum yang difermentasi dengan metode substrat padat memiliki indeks penyerapan air yang lebih tinggi dari kontrol. Nilai WAI bergantung pada keberadaan grup hidrofilik yang akan berikatan dengan molekul air. Semakin rendah kemampuan dalam menyerap air maka akan semakin berkurang jumlah ketersediaan dari grup hidrofilik yang akan berikatan dengan molekul air (Afoakwa dan Aidoo, 2006; Mbofung et al., 2006). Nilai WAI pada tepung akan menentukan kapasitas pembentukan gel dari makromolekul seperti karbohidrat dan protein.

Kekuatan pembengkakan tepung sorgum dari biji hasil perlakuan fermentasi secara substrat padat dan substrat terendam tersaji pada Tabel 3. Nilai kekuatan pembengkakan tepung tertinggi dimiliki oleh tepung sorgum dengan fermentasi secara substrat terendam selama 72 jam dengan nilai $1033,56 \%$, dan yang paling rendah dimiliki oleh tepung sorgum dengan fermentasi substrat padat selama 60 jam. Perlakuan fermentasi substrat padat pada sorgum dihasilkan nilai swelling yang lebih rendah jika dibandingkan dengan perlakuan fermentasi substrat terendam dan tepung sorgum tanpa perlakuan. Kekuatan pembengkakan pada tepung menggambarkan kemampuan pati berinteraksi dengan molekul air (Chanapamokkhot dan Thongngam, 2007). Rendahnya nilai kekuatan pembengkakan pada tepung fermentasi substrat padat kemungkinan disebabkan pada proses fermentasi biji sorgum, pati sorgum telah membengkak dan tergelatinisasi pada proses pemasakan sorgum sebelum diinokulasi dengan ragi tempe. Hal ini mengakibatkan tepung sorgum tidak bisa mengikat air secara maksimal. Penurunan kekuatan pembengkakan bisa juga disebabkan oleh perubahan bentuk dari amorphous amilosa ke dalam bentuk helik kristalin (Adebowalea et al., 2005; Olayinkaa et al., 2008).

Tabel 3. Pengaruh fermentasi biji sorgum secara substrat padat dan substrat terendam terhadap karakteristik fisik tepung sorgum

\begin{tabular}{|c|c|c|c|}
\hline Perlakuan & $\begin{array}{c}\text { Particle } \\
\text { Size Index } \\
\text { PSI (\%) }\end{array}$ & $\begin{array}{c}\text { Water } \\
\text { Absorption } \\
\text { Index WAI } \\
(\%)\end{array}$ & $\begin{array}{l}\text { Swelling } \\
\text { Power } \\
\text { (\%) }\end{array}$ \\
\hline $\begin{array}{l}\text { Sorgum tanpa } \\
\text { fermentasi } \\
\text { (Kontrol) }\end{array}$ & $55,96 \pm 0,02^{\mathrm{C}}$ & $2,79 \pm 0,12^{c}$ & $865,08 \pm 0,59^{\circ}$ \\
\hline $\begin{array}{l}\text { Sorgum } \\
\text { fermentasi } \\
\text { substrat padat } \\
60 \text { Jam }\end{array}$ & $60,47 \pm 0,3^{\mathrm{b}}$ & $3,34 \pm 0,09^{a}$ & $396,27 \pm 0,69^{d}$ \\
\hline $\begin{array}{l}\text { Sorgum } \\
\text { fermentasi } \\
\text { substrat padat } \\
72 \text { Jam }\end{array}$ & $61,40 \pm 0,3^{\mathrm{b}}$ & $3,16 \pm 0,15^{\mathrm{b}}$ & $631,69 \pm 0,22^{\mathrm{c}}$ \\
\hline $\begin{array}{l}\text { Sorgum } \\
\text { fermentasi } \\
\text { substrat } \\
\text { terendam } 72 \text { Jam }\end{array}$ & $59,99 \pm 0,3^{\mathrm{D}}$ & $2,94 \pm 0,05^{c}$ & $1033,55 \pm 0,45^{\mathrm{a}}$ \\
\hline $\begin{array}{l}\text { Sorgum } \\
\text { fermentasi } \\
\text { substrat } \\
\text { terendam } 84 \text { Jam }\end{array}$ & $64,37 \pm 0,3^{\mathrm{a}}$ & $2,92 \pm 0,06^{c}$ & $991,01 \pm 0,38^{a}$ \\
\hline \multicolumn{4}{|c|}{$\begin{array}{l}\text { Keterangan: } \mathrm{PSI}=\text { Particle size indexs (Indeks Ukuran } \\
\text { partikel); WAI = Water absorption Indexs (Indeks } \\
\text { penyerapan air). Data } \pm \text { Standar deviasi dari tiga } \\
\text { ulangan. Angka yang diikuti huruf yang sama pada } \\
\text { kolom yang sama menunjukkan tidak berbeda nyata } \\
\text { dengan uji Duncan dengan taraf } P=0,05\end{array}$} \\
\hline
\end{tabular}

\section{Sifat amilografi tepung sorgum}

Sifat fungsional terpenting dari tepung atau pati adalah sifat pasta. Keberadaan komponen lain seperti protein dan lemak pada tepung akan mempengaruhi suhu awal dan gelatinisasi sehingga sifat pasta tepung akan berbeda dengan sifat pasta patinya. Suhu awal gelatinisasi merupakan suhu awal pada saat viskositas meningkat karena terjadi pembengkakan granula sehingga struktur semikristalin rusak dan sifat birefringent hilang (Colonna dan Buleon, 2010). Sedangkan waktu awal gelatinisasi merupakan awal saat tepung mulai membentuk gel, berubah sifat viskositas dan mulai kehilangan bentuk asli. Granula pati menyerap air, serta menjadi lebih mudah di degradasi oleh enzim (Biliaderis, 2009). 
Hasil penelitian (Tabel 4) menunjukkan bahwa tepung sorgum yang dihasilkan dari biji sorgum yang terfermentasi memiliki suhu gelatinisasi antara 78,0 sampai $94,1^{\circ} \mathrm{C}$. Penurunan suhu gelatinisasi tepung sorgum hasil fermentasi 72 jam mengindikasikan bahwa ikatan mikrostruktur pada tepung hasil perlakuan fermentasi menjadi lemah. Grup hidroksil tersebut akan menyerap air dan lebih mudah mengembang selama proses pemanasan (Pranoto et al., 2013). Suhu gelatinisasi tepung sorgum sangat beragam tergantung lingkungan tempat budidaya. Beta et al. (2000) melaporkan bahwa sorgum yang tumbuh di Afrika Selatan memiliki suhu gelatinisasi berkisar $67-73^{\circ} \mathrm{C}$. Sedangkan sorgum yang tumbuh di India memiliki suhu gelatinisasi berkisar $71-81^{\circ} \mathrm{C}$.

Viskositas maksimum tepung sorgum hasil fermentasi metode substrat padat cenderung jauh lebih rendah dibanding dengan viskositas maksimum tepung sorgum tanpa fermentasi. Turunnya viskositas maksimum tepung dapat disebabkan karena fermentasi substrat padat yang dipakai adalah adopsi fermentasi tempe, dimana biji sorgum mengalami sekuen perlakuan antara lain perebusan, fermentasi dan pengeringan yang dapat berakibat pada termodifikasinya struktur pati pada biji sorgum. Perebusan dapat menyebabkan pati tergelatinisasi dan terputusnya sebagian ikatan glikosida pada polimer pati, sehingga dihasilkan komponen pati dengan derajat polimerisasi lebih pendek. Jamur yang didominasi oleh Rhizopus selama fermentasi dapat menyebabkan degradasi pati lebih lanjut, karena Rhizopus dapat menghasilkan berbagai enzim antara lain glikoamilase (Yu dan Hang, 1991) yang berperan memecah pati sampai dihasilkan unit terkecil penyusunnya yaitu glukosa. Berubahnya polimer pati menjadi struktur unit yang lebih sederhana berakibat pada dihasilkannya viskositas yang rendah bila tepung sorgum hasil fermentasi substrat padat dipanaskan.

Di sisi yang lain, viskositas maksimum tepung sorgum hasil fermentasi metode substrat terendam cenderung lebih tinggi dibandingkan dengan visko- sitas maksimum tepung sorgum tanpa fermentasi. Fermentasi substrat terendam adalah adopsi fermentasi ampok, fermentasi bersifat spontan, perendaman biji dalam air tanpa ada perlakuan panas. Selama perendaman, biji mengalami proses hidrasi hingga ke bagian terdalam. Prakondisi ini kemungkinan menyebabkan tepung (dan komponen pati) hasil fermentasi substrat terendam menjadi lebih mudah terhidrasi saat dipanaskan dalam air dan memfasilitasi lebih banyak granula pati tergelatinisasi sempurna, sehingga pada akhir pemanasan viskositas maksimum menjadi tinggi. Nilai viskositas berhubungan dengan derajat pembengkakan granula selama proses pemanasan.

Jika dikaitkan dengan data kekuatan pembengkakan (Tabel 3) tepung sorgum dengan fermentasi terendam memiliki kekuatan pembengkakan yang lebih tinggi dibandingkan dengan tepung sorgum tanpa perlakuan fermentasi. Pati dengan kapasitas pembengkakan tinggi menyebabkan viskositasnya tinggi (Chanapamokkhot dan Thongngam 2007; Ocheme et al., 2015). Tingginya nilai viskositas tepung sorgum berhubungan dengan berkurangnya amilosa pada tepung atau semakin sedikit jumlah amilosa pada sorgum (Beta et al., 2000).

\section{Bentuk mikroskopis granula pati}

Granula pati dari tepung sorghum yang diperoleh dari biji sorghum yang difermentasi menggunakan metode substrat padat dan substrat terendam, serta tanpa fermentasi secara mikroskopis disajikan pada Gambar 1. Granula pati pada kontrol nampak utuh dan lebih bulat dibanding dengan granula pati hasil fermentasi. Semakin lama fermentasi, bentuk granula pati semakin tidak beraturan, hal ini menunjukkan telah terjadi perubahan struktur pati akibat pemutusan ikatan oleh enzim yang dihasilkan mikroba selama fermentasi (Andayani, 2008; Elkhalifa dan Bernhardt, 2010). Perubahan struktur inilah yang menyebabkan perubahan karakter seperti daya serap air, viskositas dan juga gelatinisasi pati seperti yang telah dijelaskan di atas.

Tabel 4. Pengaruh fermentasi biji sorgum secara solid state dan submerged terhadap sifat amilografi tepung sorgum

\begin{tabular}{lcccc}
\hline \multicolumn{1}{c}{ Perlakuan } & $\begin{array}{c}\text { Suhu Awal } \\
\text { Gelatinisasi }\left({ }^{\circ} \mathrm{C}\right)\end{array}$ & $\begin{array}{c}\text { Suhu Gelatinisasi } \\
\left({ }^{\circ} \mathrm{C}\right)\end{array}$ & $\begin{array}{c}\text { Waktu Awal } \\
\text { Gelatinisasi (menit) }\end{array}$ & $\begin{array}{c}\text { Viskositas Max } \\
(\mathrm{BU})\end{array}$ \\
\hline $\begin{array}{l}\text { Sorgum tanpa fermentasi } \\
\text { (Kontrol) }\end{array}$ & 73,1 & 84,6 & 28,5 & 1507 \\
$\begin{array}{l}\text { Sorgum fermentasi substrat } \\
\text { padat60 Jam }\end{array}$ & 77,3 & 79,9 & 32 & 34 \\
$\begin{array}{l}\text { Sorgum fermentasi substrat } \\
\text { padat72 Jam }\end{array}$ & 75,8 & 94,1 & 30,5 & 290 \\
$\begin{array}{l}\text { Sorgum fermentasi substrat } \\
\text { terendam 72 Jam }\end{array}$ & 73,6 & 78,0 & 29 & $2000^{*}$ \\
$\begin{array}{l}\text { Sorgum fermentasi substrat } \\
\text { terendam 84 Jam }\end{array}$ & 74,0 & 80,5 & 29,5 & 1946 \\
\hline Kerangan: ${ }^{*}$ menihi kemampuan & & &
\end{tabular}




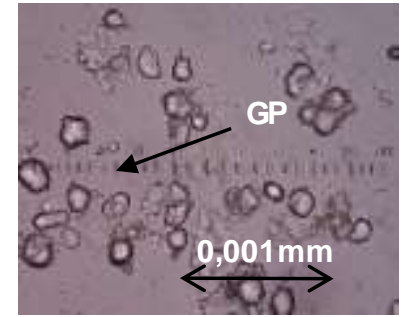

Tepung sorgum fermentasi substrat terendam 72 jam

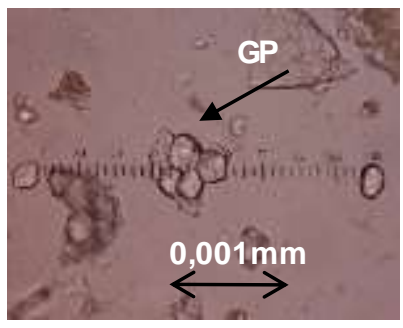

Tepung sorgum fermentasi subs trat padat 60 jam

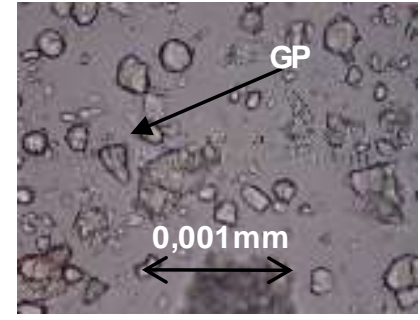

Tepung sorgum fermentasi substrat terendam 84 jam

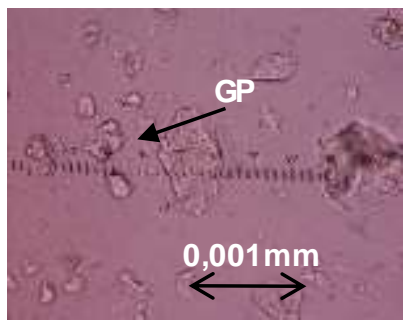

Tepung sorgum fermentasi substrat padat 72 jam

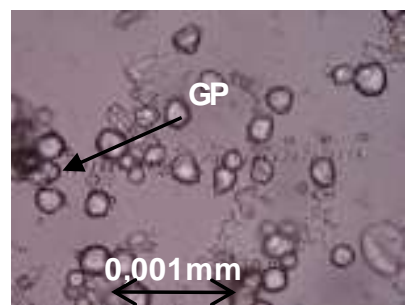

Tepung sorgum tanpa fermentasi (Kontrol)

Gambar 1. Bentuk mikroskopis granula pati tepung sorgum hasil perlakuan fermentasi metode substrat padat dan substrat terendam dengan perbesaran 400x. GP: Granula Pati

\section{KESIMPULAN}

Perlakuan fermentasi metode substrat padat dan substrat terendam pada biji sorgum berpengaruh terhadap kadar proksimat dan sifat fisik dari tepung sorgum yang dihasilkannya. Tepung sorgum yang dihasilkan dari biji sorgum yang difermentasi dengan metode substrat padat adopsi proses pembuatan tempe memiliki ukuran partikel tepung yang lebih halus, water absorption index yang lebih tinggi, swelling power dan viskositas yang lebih rendah dari tepung kontrol. Berdasarkan karakter tersebut, tepung ini sangat sesuai untuk diaplikasikan pada produk cair, misalnya bubur. Sementara tepung sorgum yang didapatkan dari biji yang difermentasi dengan metode submerged adopsi proses pembuatan ampok memiliki karakter swelling power dan viskositas yang tinggi, sangat prospektif untuk kedepan diaplikasikan untuk pangan yang memerlukan sifat kental, misalnya bahan pengental/ pengisi.

\section{DAFTAR PUSTAKA}

[AACC] American Association of Cereal Chemists. 1995. Approved Methods of the American Association of Cereal Chemists 9th Ed. MN, USA: St. Paul.

Adebowalea KO, Olu-Owolabi BI, Olayinkaa OO, Lawal OS. 2005. Effect of heat moisture treatment and annealing on physicochemical properties of red sorghum starch. Afr J Biotechnol 4: 928-933.

Afoakwa EO, Aidoo PR. 2006. Effect of solid state fermentation on the physico-chemical, functional and textural properties of nixta-malized maize. Int J Food Eng 2: 1-13. DOI: 10.2202/ 1556-3758.1061.

Aini N, Hariyadi P, Muchtadi TR, Andarwulan N. 2010. Hubungan antara waktu fermentasi grits jagung dengan sifat gelatinisasi tepung jagung putih yang dipengaruhi ukuran partikel. J Teknol Industri Pangan 21: 18-24.

Althwab S, Carr TP, Weller CL, Dweikat IM, Schlegel V. 2015. Advances in grain sorghum and its co-products as a human health promoting dietary system. Food Res Int 77: 349-359. DOI: 10.1016/j.foodres.2015.08.011.

Andayani P. 2008. Isolasi dan Identifikasi Mikroba dari Tempe Sorgum Coklat (Sorghum Bicolor) serta Potensinya dalam Mendegradasi Pati dan Protein. [Skripsi]. Malang: Fakultas Teknologi Pertanian, Universitas Brawijaya.

Awika JM, Rooney LW. 2004. Sorghum phytochemicals and their potential impact on human health. Phytochemistry 65: 1199-1221. DOI: 10.1016/j.phytochem.2004.04.001.

Belton PS, Taylor JRN. 2004. Sorghum and millets: protein sources for Africa. Trends Food Sci Tech 15: 94-98. DOI: 10.1016/j.tifs.2003.09. 002.

Beta THC, Corke H, Rooney LW, Taylor JRN. 2000. Starch properties as affected by sorghum grain chemistry. J Sci Food Agr 81: 245-251. DOI: 10.1002/10970010(20010115)81:2<245:AIDJSFA805>3.0.CO;2-S.

Biliaderis CG. 2009. Structural Transitions and Related Physical Properties of Starch. In Book: Starch: Chemistry and Technology, Third Edition. Editor: James BeMiller and Roy Whistler. 293-372. Academic Press. New York. USA.

Chanapamokkhot H, Thongngam M. 2007. The chemical and physicochemical properties of 
sorghum starch and flour. Kasetsart J Nat Sci 41: $343-349$.

Colonna P, Buleon A. 2010. Thermal Transitions of Starches. In Book: Starches: Characterization, Properties, and Applications, Editor: Andréa C. Bertolini. 71-102. CRC Press. Boca Raton, Florida. USA.

Cuevas-Rodriguez EO, Milan-Carrillo J, MoraEscobedo R, cardenas-Valenzuela OG, ReyesMoreno C. 2004. Quality protein maize (Zea mays L) tempeh flour through solid state fermentation process. LWT-Food Sci Technol 37: 59-67. DOI: 10.1016/S0023-6438(03)00 134-8.

Cuevas-Rodriguez EO, Verdugo-Montoya NM, Angulo-Bejarano PI, Milan-Carrillo J, MoraEscobedo R, Bello-Perez LA, Garzon-Tiznado JA, Reyes-Moreno C. 2006. Nutritional properties of tempeh flour from quality protein maize (Zea mays L.). LWT-Food Sci Technol 39: 1072-1079. DOI: 10.1016/j.Iwt.2005.07.003.

de Mesa-Stonestreet NJ, Alavi S, Bean SR. 2010. Sorghum proteins: The concentration, isolation, modification, and food applications of kafirins. J Food Sci 75: R90-R104. DOI: 10.1111/j.17503841.2010.01623.x.

Dicko MH, Gruppen H, Alfred S. Traoré AS, Voragen AGJ, van Berkel, WJH. 2006. Sorghum grain as human food in Africa: relevance of content of starch and amylase activities. Afr $\mathrm{J}$ Biotechnol 5: 384-395.

Duodu KG, Taylor JRN, Belton PS, Hamaker BR. 2003. Factors affecting sorghum protein digestibility. J Cereal Sci 38: 117-131. DOI: 10.1016/ S0733-5210(03)00016-X.

Elbaloula MF, Yang R, Guo Q, Gu Z. 2014. Major nutrient compositions and functional properties of sorghum flour at 0-3 days of grain germination. Int J Food Sci Nutr 65: 48-52. DOI: 10.3 109/09637486.2013.836736.

Elkhalifa AEO, Schiffler B, Bernhardt R. 2005. Effect of fermentation on the functional properties of sorghum flour. Food Chem 92: 1-5. DOI: 10.10 16/j.foodchem.2004.05.058.

Elkhalifa, AEO, Schiffler B, Bernhard R. 2004. Effect of fermentation on the starch digestibility, resistant starch and some physicochemical properties of sorghum flour. Mol Nutr Food Res 48: 91-94. DOI: 10.1002/food.200300322.

Elkhalifa AEO, Bernhardt R. 2010. Influence of grain germination on functional properties of sorghum flour. Food Chem 121: 387-392. DOI: 10.1016/ j.foodchem.2009.12.041.

[FAO] Food Agricultural Organization. 1995. Sorghum and millets in human nutrition.
http://www.fao.org/DOCREP/T0818e/T0818E01

.htm. [25 Desember 2008].

Farasara R, Hariyadi P, Fardiaz D, Dewanti-Hariyadi R. 2014. Pasting properties of white corn flours of Anoman 1 and Pulut Harapan varieties as affected by fementation process. Food Nutr Sci 5: 2038-2047. DOI: 10.4236/fns.2014.521215.

Feng XM. 2006. Microbial Dynamics During Barley Tempeh Fermentation. [Dissertation]. Faculty of Natural Resources and Agricultural Sciences, Department of Microbiology, Swedish University of Agricultural Sciences. Uppsala.

Hassan AB, Ahmed IAM, Osman NM, Eltayeb MM, Osman GA, Babiker EE. 2006. Effect of processing treatments followed by fermentation on protein content and digestibility of pearl millet (Pennisetum typhoideum) cultivars. Pak J Nutr 5: 86-89. DOI: 10.3923/pjn.2006.86.89.

Inyang CU, Zakari UM. 2008. Effect of germination and fermentation of pearl millet on proximate, chemical and sensory properties of instant "Fura"- a Nigerian cereal food. Pakistan J Nutr 7: 9-12. DOI: 10.3923/pjn.2008.9.12.

Kaufman RC, Herald TJ, Bean SR, Wilson JD, Tuinstra MR. 2013. Variability in tannin content, chemistry and activity in a diverse group of tannin containing sorghum cultivars. J Sci Food Agr 93: 1233-1241. DOI: 10.1002/jsfa.5890.

Kayode APP, Mertz C, Guyot J, Brat P, Mouquetrivier C. 2013. Fate of phytochemicals during malting and fermentation of Type III tannin sorghum and impact on product biofunctionality. J Agr Food Chem 61: 1935-1942. DOI: 10. 1021/jf304967t.

Kohajdova Z, Karovicona J. 2007. Fermentation of cereals for Spesific purpose. J Food Nutr Res 46: 51-57.

Mbofung CMF, Aboubakar YNN, Bouba AA, Balam F. 2006. Physicochemical and functional properties of sio Varieties of Taro (Colocasia esculante L. Schott) flour. J Food Technol 4: 135-142.

Murtini ES, Radite AG, Sutrisno, A. 2011. Karakteristik kandungan kimia dan daya cerna tempe sorgum coklat (Sorghum bicolor). J Teknol Industri Pangan 22: 150-155.

Ocheme OB, Adedeji OE, Lawal G, Zakari UM. 2015. Effect of germination on functional properties and degree of starch gelatinization of sorghum flour. J Food Res 4: 159-165. DOI: 10.5539/jfr.v4n2p159.

Olayinkaa OO, Adebowale KO, Olu-Owolabi BI. 2008. Effect of heat-moisture treatment on physicochemical properties of white sorghum 
starch. Food Hydrocolloid 22: 225-230. DOI: 10.1016/j.foodhyd.2006.11.004.

Pontieri P, Mamone G, De Caro S, Tuinstra MR, Roemer $E$, Okot J, De vita P, Ficco DBM, Alifano $P$, Pignone D, Massardo DR, Del Giudice L. 2013. Sorghum, a healthy and gluten-free food for celiac patients as demonstrated by genome, biochemical, and immunochemical analyses. J Agr Food Chem 61: 2565-2571. DOI: 10.1021/jf304882k.

Pranoto Y, Anggrahini S, Efendi Z. 2013. Effect of natural and Lactobacillus plantarum fermentation on in-vitro protein and starch digestibilities of sorghum flour. Food Bioscience 2: 46-52. DOI: 10.1016/j.fbio.2013.04.001.

Rahmawati, Dewanti-Hariyadi R, Hariyadi P, Fardiaz D, Richana N. 2013. Isolation and identification of microorganisms during spontaneous fermentation of maize. J Teknol Industri Pangan 24: 33-39. DOI: 10.6066/jtip.2013.24.1.33.

Schons PF, Battestin V, Macedo GA. 2012. Fermentation and enzyme treatments for sorghum. Braz J Microbiol 43: 89-97. DOI: 10.1590/S1 517-83822012000100010.

Serna-Saldivar S. Rooney LW. 1995. Structure and Chemistry of Sorghum and Millets. In: Sorghum and Millets: Chemistry and Technology, Editor: David A.V. Dendy. 69-124. American Association of Cereal Chemists, St. Paul, USA.

Singh J, Dartois A, Kaur L. 2010. Starch digestibility in food matrix: a review. Trends Food Sci Tech 21: 168-180. DOI: 10.1016/j.tifs.2009.12.001.

Soeranto, 2006. Pemuliaan tanaman sorgum di PETIR-BATAN. http://www.batan.go.id/patir/berita/pertanian/sorgum/sorgum.htm. [12 Oktober 2007].
Sujatmiko B. 2009. Degradasi Senyawa Tanin, Asam Fitat, Antitripsin dan Peningkatan Daya Cerna Protein Secara in vitro pada Sorgum Coklat (Sorghum bicolor L. Moench) dengan metode Fermentasi Ampok [Skripsi]. Malang: Fakultas Teknologi Pertanian, Universitas Brawijaya.

Taylor JRN, Anyango JO. 2011. Sorghum Flour and Flour Products: Production, Nutritional Quality, and Fortification. In: Flour and Breads and their Fortification in Health and Disease Prevention, Editor: V. Preedy, R. Watson, \& V. Patel. 127139. Elseviers Science \& Technology Rights Departement in Oxford. DOI: 10.1016/B978-012-380886-8.10012-1.

Taylor JRN, Duodu KG. 2014. Effects of processing sorghum and millets on their phenolic phytochemicals and the implications of this to the health-enhancing properties of sorghum and millet food and beverage products. J Sci Food Agr 95: 225-237. DOI: 10.1002/jsfa.6713.

Taylor J, Taylor JRN. 2011. Protein biofortified sorghum: Effect of processing into traditional African foods on their protein quality. J Agr Food Chem 59: 2386-2392. DOI: 10.1021/j f104006v.

Utami D. 2008. Isolasi dan Identifikasi Mikroba dari Fermentasi Ampok Sorgum Coklat (Sorgum bicolor L. Moench) serta Potensinya dalam Mendegradasi Pati dan Protein [Skripsi]. Malang: Fakultas Teknologi Pertanian, Universitas Brawijaya.

Yu RC, Hang YD. 1991. Purification and characterization of glucoamylase from Rhizopus oryzae. Food Chem 40: 301-308. DOI: 10.1016/03088146(91)90114-4. 